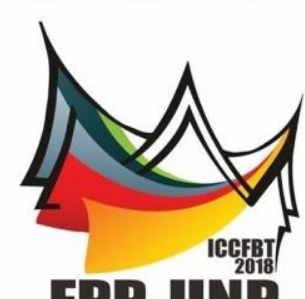

FPP-UNP

PROCEEDING

The $1^{\text {st }}$

ICGFBT 2018

INTERNATIONAL CONFERENCE ON CULINARY.

FASHION, BEAUTY AND TOURISM

Enfigfitening The World Tfurougf ICCEBT 2018

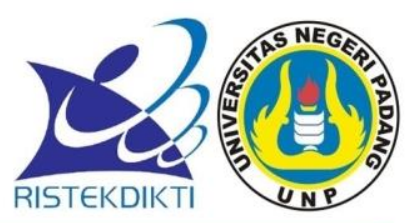

Auditorium Universitas Negeri Padang 


\section{PROCEEDING}

The $1^{\text {st }}$ International Conference on

Culinary, Fashion, Beauty, and Tourism (ICCFBT)

Theme:

“Creative Economic and Sustainable Tourism Towards Digital Globalization”

Padang, May $11^{\text {th }}-12^{\text {th }}, 2018$

Speaker:

Prof. Kaye Chon (Poly U Hongkong)

Prof. Dr. Mohd Salehuddin Mohd Zahari (University Teknologi Mara Malaysia)

Dr. Martha Tilaar (CEO Martha Tilaar Group)

Prof. David Hind (President of The Asia Pasific Institute for Event Management; Distinguished Proffesor at Chung Hua University, Taiwan and Visiting Proffesor at London Metropolitan University, UK)

\section{Fakultas Pariwisata dan Perhotelan Universitas Negeri Padang (FPP UNP)}




\section{PROCEEDING}

The $1^{\text {st }}$ International Conference on

Culinary, Fashion, Beauty, and Tourism (ICCFBT)

Theme:

"Creative Economic And Sustainable Tourism Towards Digital Globalization"

\section{Steering Committee:}

Prof. Ganefri, Ph.D

Dra. Ernawati, M.Pd, Ph.D

\section{Organizing Committee:}

Dr. Elida. M.Pd

Prof. Anni Faridah. M.Pd

Hijriyantomi Suyuthie, S.Ip, MM

Resi Yulia, SE, MM

Dra. Rahmiati, M.Pd, Ph.D

Indralena, SH. M.Pd

Dr. Yuliana, S.P, M.Si

Heru Pramudia, S.ST, M.Par

Pasaribu, SST.Par, M.Si.Par

Medris. S.Kom, M.Cio

Waryono, S.Pd, MM.Par

Dra. Ira Meirina Chair, M.Pd

Murni Astuti, S.Pd, M.Pd.T

Merita Yenita, S.Pd, M.Pd.T

Dra. Wirnelis Syarif, M.Pd

Dra. Lucy Fridayati, M.Kes

\section{CHIEF EDITOR:}

Dr. Yuliana, SP., M.Si

\section{EDITORS AND REVIEWERS:}

1. Prof. Kaye Chon - Poly U Hong Kong

2. Prof. Dr. Mohd. Salahuddin Mohd Zahari - University Teknologi Mara Malaysia

3. Prof. David Hind - Asia Pacific Institute

4. Krismadinata, ST,MT, Ph.D - Universitas Negeri Padang

5. Yohandri, M.Si., Ph. D - Universitas Negeri Padang

6. Dr. Rahadian .Z, S.Pd, M.Si - Universitas Negeri Padang

7. Ifdil, S.HI, S.Pd., M.Pd., Ph.D.Kons

8. Dra. Asmar Yulastri, M.Pd, Ph.D

9. Dr. Yenni ldrus, M.Pd 
10. Dr. Linda Rosalina, M.Biomed

11. Trisna Putra, SS, M.Sc

\section{LAYOUT EDITOR}

Cover

: Tourism and Hospitality Promotions

Content Layout

: Feri Ferdian, SST.,M.M

Hendri Azwar, S.ST Par., M.Par

Drs. Andriwifa, M.Si

\section{Published by}

Fakultas Pariwisata dan Perhotelan

Universitas Negeri Padang (FPP UNP)

Jl. Prof. Dr. Hamka Air Tawar Kota Padang

Sumatera Barat, Indonesia

Telp: 0751-7051186

Email: tourismconference@fpp.unp.ac.id

Website: tourismconference.fpp.unp.ac.id

ISBN 978-602-52249-0-4

All Right Reserved

No Part of Publication May Be Reproduce Without Written Permission of The Publisher 


\title{
QUALITY WET NOODLES WITH SUBSTITUTION OF MAIZE
}

\author{
Ade Irferamuna, 'Anni Faridah, 'Kasmita \\ Home Economics Education Study Program \\ Faculty of Engineering, Universitas Negeri Padang \\ Email: adeirferamuna@gmail.com
}

\begin{abstract}
Increased production of corn per year from 2011 to 2013. One way to optimize the use of corn can be done by substituting the flour in food processing. This study Aimed to analyze the quality of wet noodles with corn substitution as much as 0,30, 40, and 50\% that includes the color, aroma, flavor, and texture. This type of research is pure experimentation (true experimentation) with a completely randomized design method of three repetitions. Results of hypothesis testing Showed there are significant levels in each treatment. Quality produced generated in this study are quite yellow color, quite flavorful corn aroma, flavor was tasty enough and tasted enough maize, the texture is chewy and rather not Easily broken. Based on the hedonic test, panelists preferred the substitution of $30 \%$. The best quality of wet noodles with corn noodle substitution is the substitution of $30 \%$.
\end{abstract}

KEYWORDS: corn, wet noodle, quality of wet noodle

\section{INTRODUCTION}

Noodles is a very popular international food for every age group, both from children and the elderly. People consume a lot of noodles as alternative food substitute for rice. Noodles are often consumed by the community is a kind of instant noodles, dry noodles, and wet noodles. Deddy Rustandi (2011: 8), Grouping of noodles based on basic ingredients or raw materials, divided into two noodles that are flour and noodles are defended non-wheat flour.

However, the usual noodles enjoyed by the community are noodles made from wheat flour, while wheat is still imported. Based on data from the Association of Indonesian Wheat Flour Producers (APTINDO) (2012: 2), domestic flour consumption reached 1.22 million tons in the first quarter of 2012, up 5.61 percent compared to the same period in 2011 which recorded 1.15 million tons. Therefore, imports of wheat continue to increase. Corn has a high enough protein content that can replace wheat flour. The nutritional composition of fresh corn seeds is $33.1 \mathrm{~g}$ of carbohydrates, $4.7 \mathrm{~g}$ protein, $1.3 \mathrm{~g}$ fat, $6 \mathrm{mg}$ of calcium, $118 \mathrm{mg}$ of phosphorus, vitamin A $435 \mathrm{mg}$, vitamin B $0.24 \mathrm{mg}$, and vitamin C $8 \mathrm{mg}$.

The selection of maize to be substituted in the manufacture of wet noodles in addition to having the same high protein content, can also increase the nutritional value of wet noodles, which is to increase the content of vitamin A and phosphorus high and low fat in wet noodles. Therefore this study aims to analyze "Quality Wet Noodles With Substitution of Corn $0,30,40$, and $50 \% "$.

2. METHODS

1. Research type

The type of research conducted is pure experiments (true experiment) that is a direct experiment method of substitution of corn in the manufacture of wet noodles

2. Location and Schedule Research

This research was conducted in Culinary Workshop, Home Economics Education Program, Faculty of Engineering, State University of Padang. The study was conducted from April to May 2015.

3. Research procedure

a. Preparation 
Before doing the processing, prepared materials and tools to be used in the manufacture of wet noodles. The ingredients that need to be prepared are high protein flour, smoothed corn, eggs, salt, and baking soda. The equipment needed in this research is digital scales, stainless steel waschers, measuring cups, tablespoons, presses, stove noodle and boiling container.

\section{b. Stage Research}

In this study, the standard recipe used is a recipe from Suyanti (2010: 43), namely high protein flour ( $250 \mathrm{gr})$, egg ( $50 \mathrm{gr}$ ), salt ( $2.5 \mathrm{gr})$, and baking soda $(2 \mathrm{~g})$, while for research recipes, fresh corn will be used $30 \%, 40 \%$, and $50 \%$ of the amount of flour used, and the amount of flour will be reduced according to the use of maize. The process of making wet noodles with susbtitusi maize, can be seen in Figure 1.

\section{c. Assessment Stage}

Wet noodles that have been cooked, then performed the stage of organoleptic testing. Wet noodles that have been cooked are placed in containers that have been given the sample code, then each sample is placed on the panelist table. Panelists provide an assessment of wet noodles without the use of corn and wet noodles that use corn as much as $30 \%, 40 \%$, and $50 \%$ of the quality of wet noodles in order to see the difference from the criteria written on the information sheet.

\section{RESULTS AND DISCUSSION}

Based on organoleptic test (histone test and hedonic test) which have been done to the quality of wet noodle with corn substitution covering color, aroma, flavor, and texture, hence obtained result of research as follows.

\subsection{Results}

a. Description of Average Data on the Effect of Wet Noodle Quality with Substitution of Maize $(30 \%, 40 \%$, and $50 \%)$ with Level Test

b. Based on figure 2 above, we can describe the average value of the level test on the color quality (yellow) of wet noodles with the substitution of maize on the control $0 \%(\mathrm{X} 0)$ has an average value of 3.1 with sufficient yellow category, in substitution of $30 \%(X 1)$ has an average value of 3.17 with the yellow-sufficient category, in substitution of $40 \%$ (X2) has an average value of 3.28 with sufficient yellow category, and the substitution of $50 \%$ (X3) averages 3.33 with category is quite yellow.

c. On the quality of the wet noodle (corn) aroma with the substitution of maize is: $0 \%$ control $(\mathrm{X} 0)$ has an average value of 1.53 with the category not aroma of corn, the substitution of $30 \%(X 1)$ has an average value of 3.21 with category is quite corn-flavored, the substitution of $40 \%$ (X2) has an average value of 3.21 with enough corn-scented categories, and substitution of $50 \%$ (X3) an average value of 3.26 with enough corn-scented categories.

On the quality of the taste (savory) wet noodles with the substitution of maize is: $0 \%$ control (X0) has an average value of 3.27 with the category is quite tasty, the substitution of $30 \%(X 1)$ has an average value of 3.26 with enough category tasty, the substitution of $40 \%$ (X2) has an average value of 3.24 with a fairly tasty category, and the substitution of $50 \%$ (X3) averaged 3.24 with a fairly savory category. 


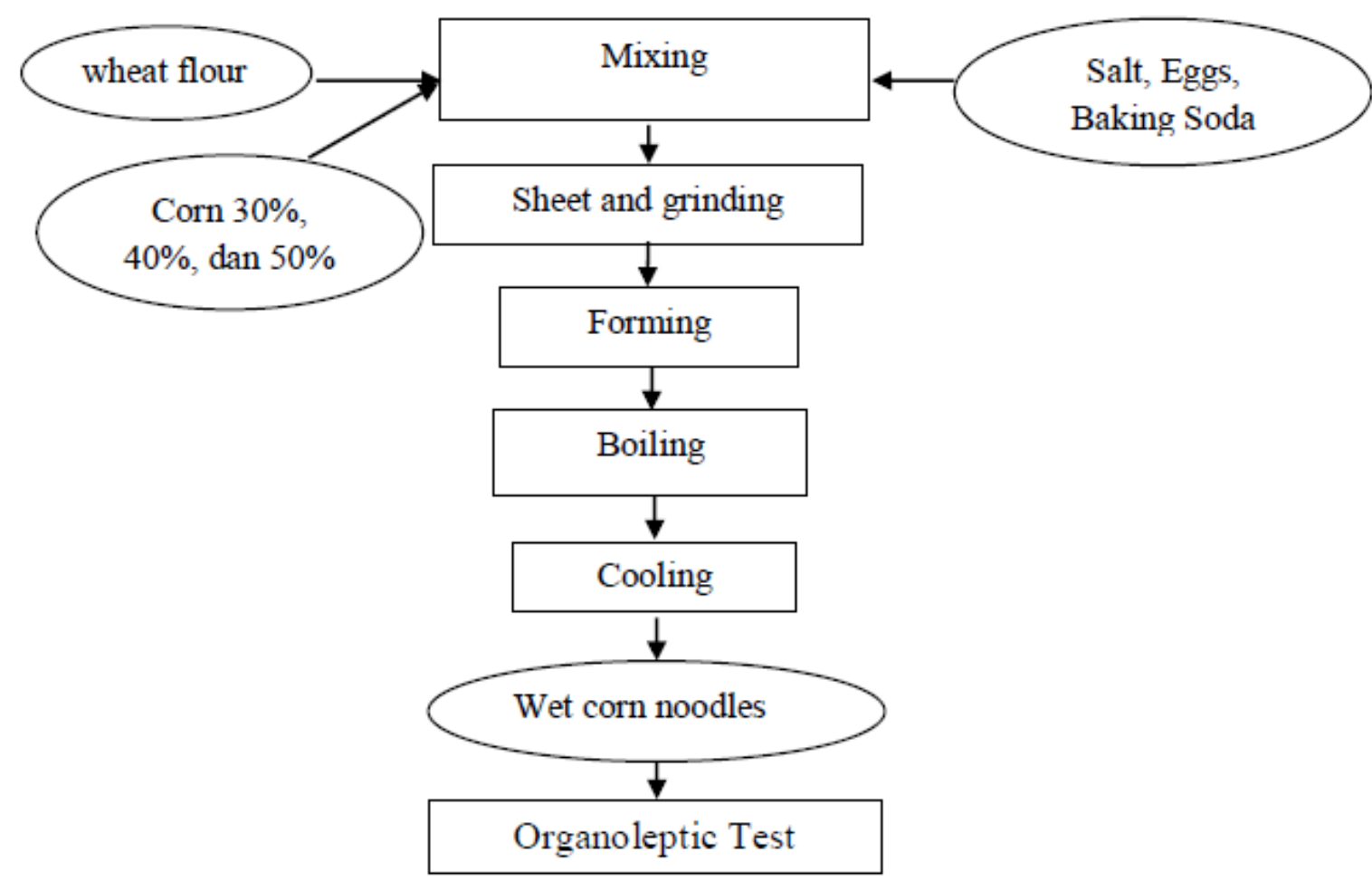

y

ure 1. Flow Chart of Wet Noodle Making Process of Maize

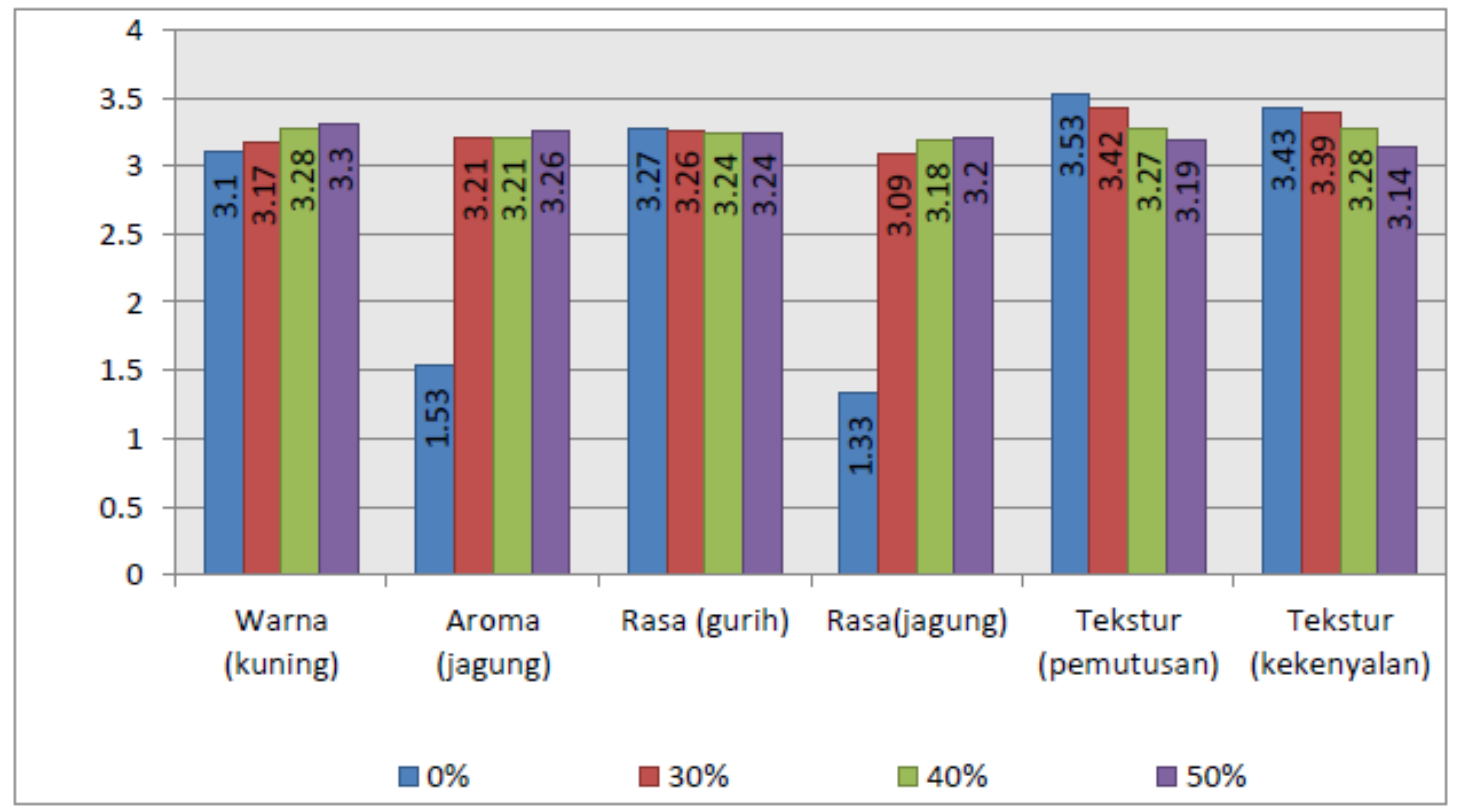

Figure 2. Description of Average Data Score Test of Quality Level of Wet Noodles with Substitution of Maize 


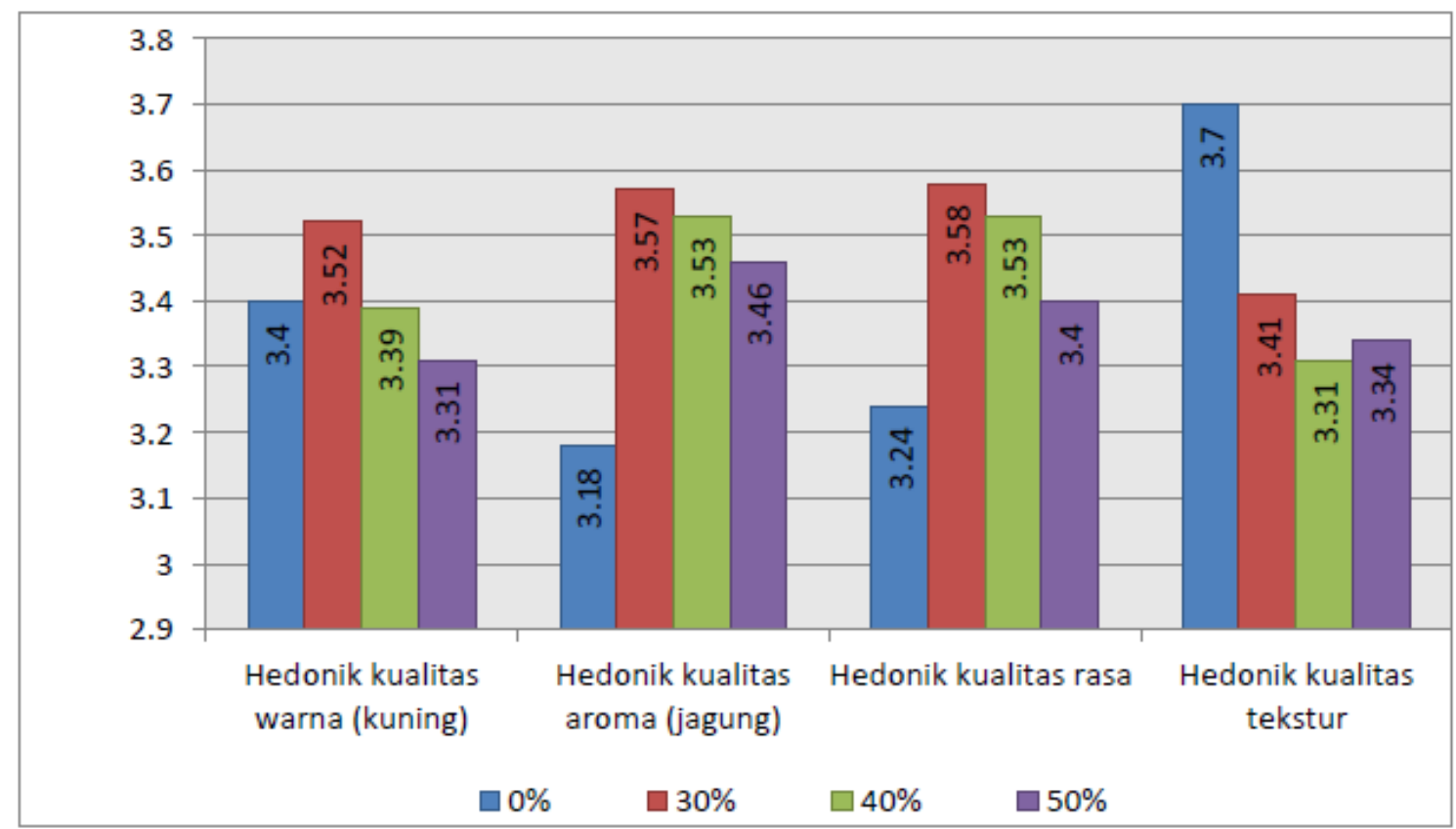

Figure 3. Data Description Average Hedonic Test Score of Wet Noodle Quality with Substitution of Maize

On the taste quality (corn) of wet noodles with the substitution of maize is: $0 \%$ control $(\mathrm{X} 0)$ has an average value of 1.33 with the category of corn felt, the substitution of $30 \%$ (X1) has an average value of 3.09 with the category close to corn taste, in substitution of $40 \%$ (X2) has an average value of 3.18 with the category of corn taste and substitution of $50 \%$ (X3) averaged 3.20 with a sufficiently corny category

On the texture quality of the wet noodles with the substitution of maize: $0 \%$ control $(\mathrm{X} 0)$ has an average value of 3.53 with the category close to chewy, the substitution of $30 \%$ (X1) has an average value of 3.42 with enough category chewy, the substitution of $40 \%$ (X2) has an average value of 3.27 with the category is quite chewy, and substitution $50 \%$ (X3) average value 3.19 with the category is quite chewy.

On the quality of texture (disconnection) of wet noodles with the substitution of maize namely: $0 \%$ control (X0) has an average value of 3.43 with the approaching category is not easily broken, the substitution of $30 \%$ (X1) has an average value of 3.39 with the approximate category is somewhat inconvenient, in the substitution of $40 \%$ (X2) having an average value of 3.28 with the approximate category somewhat not easily broken, and the substitution of $50 \%$ (X3) the mean value of 3.14 with the approximate category is rather difficult break 
d. Description of Average Data on the Effect of Wet Noodle Quality with maize substitution $(30 \%, 40 \%$, and $50 \%)$ With Hedonic Test

Based on Figure. 3 , the average hedonic test value of the color quality (yellow) of wet noodles with corn derudes the mean value of the hedonic test each treatment is on the control $0 \%(\mathrm{X} 0)$ the average value of 3.40 with the category is quite like, in the substitution of $30 \%$ (X1) the average value of 3.52 with the category is quite like (approximate likes), the substitution of $40 \%$ (X2) the average value of 3.39 with the category quite like, and substitution $50 \%(\mathrm{X} 3)$ the average score of 3.31 with the category is quite like.

On the quality of wet noodle (corn) aroma with maize substitution, the mean hedonic test value of each treatment was control $0 \%(\mathrm{X} 0)$ the average value of 3.18 with the category is preferable, in substitution $30 \%$ (X1) in the substitution of $40 \%$ (X2) the average value of 3.53 with the category quite like (approximate likes), and the substitution of $50 \%$ (X3) the average value of 3,46 with the category quite like.

On the quality of wet noodle taste with maize substitution, the mean value of the hedonic test of each treatment was at $0 \%$ control $(\mathrm{X} 0)$ an average value of 3.24 with fairly favored category, at substitution of $30 \%(X 1)$ the mean value 3.58 with the category quite like (close to likes), the substitution of $40 \%(\mathrm{X} 2)$ the average value of 3.53 with the category quite like, and substitution $50 \%$ (X3) the average value of 3.40 with the category quite like.

On the quality of the texture of the wet noodles with the substitution of maize, the mean value of the hedonic test of each treatment was on the control of $0 \%(X 0)$ the average value of 3.70 with the category quite like (approximate likes), on substitution of $30 \%$ (X1) the average value of 3.41 with the category is quite like, the substitution of $40 \%$ (X2) the average value of 3.31 with the category quite like, and the substitution of $50 \%$ (X3) the average value of 3.34 with the category quite like.

\subsection{Discussion}

After conducting the research with a series of organoleptic tests (histological test and hedonic test) on wet noodles with four maize substitutes, ie $0 \%, 30 \%$, $40 \%$ and $50 \%$ maize substitution, the quality of wet noodles, , taste, and texture as follows.

a. The Effect of Wet Noodle Color Quality with Substitution of Maize $(0 \%$, $30 \%, 40 \%$, and $50 \%$ )

1) Test of Level Quality Color

ANAVA statistics on the color quality stated that $\mathrm{Ha}$ rejected, which means there is no effect of wet noodles with the substitution of corn to the color quality. Samples X1, X2, and X3 have a good yellow color because the use of fresh corn can help in staining noodles to be more yellow than $X 0$ samples that do not use fresh corn. According to Winarno (2004: 171) states that "a nutritious, tasty and excellent texture, will not be eaten if it has an unsightly color or gives the impression that it has deviated from its intended color".

2) Hedonic Test of Color Quality

The average hedonic color score of the $\mathrm{X} 1$ sample is preferred by the panelists, where the color of the noodles in $X 1$ is quite yellow. And on X2 and X3 the color sample of yellow noodles because of the use of fresh corn that replaces some flour so that the panelist can choose the color of food that is not too yellow. In the ANAVA hedonis table denotes that $\mathrm{Ha}$ is rejected, meaning there is no wet noodle effect with corn substitution at $0 \%, 30 \%, 40 \%$, and $50 \%$ substituted corn color. It is 
based on observations and judgments made by the panelists, so it can be concluded there is no real difference. According to Nurhayati (in Fifin, 2013: 09), "dark colors are not favored while bright colors will attract more attention". Therefore, the panelists prefer the color of wet noodles with $50 \%$ corn substitution.

b. The Effect of Wet Noodle Aroma Quality with Substitution of Maize $(0 \%$, $30 \%, 40 \%$, and $50 \%$ )

1) Test of Level Quality Aroma (Corn)

The ANAVA statistics on the quality of aroma (corn) stated that $\mathrm{Ha}$ is accepted, which means that there is an effect of the quality of wet noodle aroma with maize substitution (0\%, 30\%, 40\%, and 50\%). X3 samples were more corn-scented than those of $\mathrm{X} 0, \mathrm{X} 1$, and $\mathrm{X} 2$. This is because the sample $X 3$ is substituted by using fresh corn as much as $50 \%$ compared to the other samples, so in the quality of the aroma (corn) of sample $\mathrm{X} 0$ which is the substituent of $0 \%$, the sample $X 1$ is the substituent of $30 \%$, and the sample $\mathrm{X} 2$ is the substituent of $40 \%$, so the aroma will be further reduced. According to Winarno (2004: 200) states that the smell of food much to determine the delicacy of these foods. So the aroma of corn will increasingly appear when more and more usage.

2) Hedonic test of Aroma Quality

The X3 sample is preferred by the panelists compared to the samples $\mathrm{X} 0, \mathrm{X} 1$, and $\mathrm{X} 2$. This is because the panelist probably prefers a fairly aromatic corn. Due to the more substance of corn, it will be highly aromatic of corn. Sample XO which does not use corn is less favored by the panelists, because it does not smell corn. In Table ANAVA hedonic quality aroma of corn noodle there is influence of substituents of corn $0 \%, 30 \%, 40 \%$, and $50 \%$. This is based on observations and assessments made by the panelists, so it can be concluded there is a real difference between the three treatments. Therefore panelists prefer the hedonic quality of $30 \%$ substitution of aroma (corn).

c. The Effect of Wet Noodle Taste Quality by Substitution of Corn ( $0 \%$, $30 \%, 40 \%$, and $50 \%$ )

1) Test Of Level Quality Taste (Savory)

Based on ANOVA statistics on taste quality (savory) states that $\mathrm{Ha}$ is rejected, which means there is no effect of wet noodles with maize substitution to taste quality (savory). Sample $X 0$ has a high savory taste compared to the samples $\mathrm{X} 0, \mathrm{X} 1$ and $\mathrm{X} 2$, of which the three samples are the flour substitution with fresh corn. Due to the savory tastes contained in the $\mathrm{XO}$ sample is more pronounced than in the other samples, which tastes are influenced by the use of eggs and salt. Koswara (2005: 6) that "the addition of salt in addition to the addition of the addition of taste can preserve the results of wet noodles".

2) Test Of Level Quality Taste (Corn)

Based on the ANOVA statistics on the taste quality (corn) stated that $\mathrm{Ha}$ is accepted, which means there is influence of wet noodles with the substitution of corn to the taste quality (corn). The $\mathrm{X} 3$ sample has the dominant maize flavor compared to the samples $\mathrm{X} 1, \mathrm{X} 2$, and $\mathrm{X} 3$, of which the three samples are the flour substitution with fresh corn. Due to the taste of corn contained in the X3 sample is more pronounced than in other samples, this is because the use of corn segara more that is as much as $50 \%$ which is substituted with flour. The taste of corn will be more pronounced, when the use of corn more or more than the amount of flour used.

3) Hedonic test of Taste Quality 
Sample $\mathrm{X} 1$ has a high taste level of taste compared to samples $\mathrm{X} 0$, $X 2$, and X3. The panelists preferred because of the possibility that panelists favored the use of small maize compared to samples given more maize. So the more corn is used, the corn taste will be stronger and less savory. In the ANAVA table, the quality of noodle flavor contained $0 \%, 30 \%, 40 \%$, and $50 \%$ substitution of maize. This is based on observations and assessments made by the panelists, so it can be concluded that there is a real difference. The best substitution hedonic quality is wet noodles with maize substitution of $30 \%$

d. The Effect of Wet Noodle Texture Quality with Substitution of Corn ( $0 \%$, $30 \%, 40 \%$, and $50 \%$ )

1) Test of Level of Quality Texture (Elastic)

ANAVA statistical results on texture quality (elasticity) stated that $\mathrm{Ha}$ is accepted, which means that there is a $0 \%, 30 \%, 40 \%$, and $50 \%$ substitution of maize. Sample XO has a high viscosity, because this sample is the flour substitution with fresh corn. Sample X0 is more supple because it uses $100 \%$ wheat flour, which flour has a protein called gluten. This gluten is formed when wheat flour is moistened with water during dough preparation, gluten binds water and forms. According to Anni Faridah et al (2008: 14) states that, "high gluten content will form elastic tissue during the stirring process". Can be seen clearly gluten is very helpful in the suppleness of the dough noodles. In the sample X1, X2, and $X 3$ there is a decrease in the quality of suppleness caused by the use of flour with fresh corn will reduce the gluten content of wheat.

2) Test Of Level Of Quality Texture (Cutting)

The ANAVA statistic on texture quality (cutting) states that $\mathrm{Ha}$ is accepted, which means that there is a $0 \%, 30 \%, 40 \%$, and $50 \%$ substitution of maize. Sample $X 0$ has an unexpected in high cuts compared to the samples $\mathrm{X} 1, \mathrm{X} 2$, and $\mathrm{X} 3$, of which these three samples are the substitution of terigung flour with fresh corn. According to Suyanti (2008: 17) states that, "elastic properties on gluten will cause the noodles to be elastic so it is not easy to cut". Gluten that is elastic decreases the noodles will be easily cut off.

3) Hedonic Test of Texture Quality

Sample $\mathrm{X} 0$ has a high preference level compared to $\mathrm{X} 1, \mathrm{X} 2$, and $\mathrm{X} 3$ samples. Here panelists prefer $\mathrm{X} 0$ samples that have a good degree of elasticity and good cuts than substituted samples. The increasing use of corn will reduce the texture level of the noodles. In Table ANAVA hedonic quality of corn noodle texture seen there is influence of substituents of corn $0 \%, 30 \%, 40 \%$, and $50 \%$. This is based on observation and assessment by panelists, it is concluded that there is a real difference. The best substitution texture hedonic quality is wet noodles with $0 \%$ corn substitution.

\section{4) CONCLUSION}

The results of the analysis of the quality level of wet noodle substitution of maize is the color has no real effect and the best substitution is $50 \%$ (yellow enough). The smell is real and the best substitution is 50\% (enough aroma of corn). The taste is tasty and the best substitution is $0 \%$ (quite tasty), the corn flavor is real and the best substitution is $50 \%$ (feels corn). The texture of viscosity has real effect and the best substitution is $0 \%$ (chewy). Cutting texture has real effect and best substitution of $30 \%$ (somewhat not easily cut off).

The result of hedonic test analysis of wet noodle substitution of corn is the color has no real effect and the best substitution is $30 \%$ (quite like). The smell is real and the 
best substitution is $30 \%$ (quite like). The sense of real influence and the best substitution is $30 \%$ (quite like). The texture is real and the best substitution is $0 \%$ (close to likes).

\section{REFERENCES}

Anni Faridah et al M.Pd. 2008. patiseri volumes 1 toCMS. Jakarta: Directorate of Technical and Vocational Education

Anonymous. "Kompas.2012" Aptindo Request Security Wheatlmport. http: // www.Aptindo.Minta.Pengamanan.Terigu.Impor.com. Accessed 04 March 2013.

Astawan, M. 2006. Making noodles andvermicelli.Jakarta: Sower Self Reliance.

Rustandi, Deddy. 2011. Powerful Production MiSMEs. Solo: Pustaka Mandiri PT Triad Nutrition Directorate of the Ministry of Health of the Republic of Indonesia. (1992).

Moehyi, Sjahmien. 1992. Implementation of Institutional Food AndHospitality. Jakarta: Bhratara

Setyaningsih, Dwi. 2010. Analysis of Sensiri For Food and Agrolndustries. Bogor: IPB

Sugiyono 2006, Statistics forResearch, Seventh Molds, Bandung: CV.Alfabeta

Suyanti. 2010. Creating a Healthy Nutritious and Non MiPreservatives. Jakarta: Sower Self Reliance.

Winarno, FG 1992. Nutrition and FoodChemistry.Jakarta: PT Gramedia Pustaka Utama 